\title{
Phytoplankton community structure and productivity along the axis of the Mississippi River plume in oligotrophic Gulf of Mexico waters
}

\author{
Boris Wawrik, John H. Paul* \\ University of South Florida, 140 7th Ave S, St. Petersburg, Florida 33701, USA
}

\begin{abstract}
The Mississippi River is the largest freshwater input into the Gulf of Mexico (GOM) and contributes a large nutrient load to northern GOM waters. During the summer, the Mississippi River plume is sometimes found to extend into the eastern oligotrophic GOM as far as the Dry Tortugas. The objectives of this study were to determine the relative contribution of the Mississippi River plume to the total surface water production in the oligotrophic GOM and the impact of this feature on the composition of phytoplankton found there. Using Sea-viewing Wide Field-of-View Sensor (SeaWiFS) satellite images, we located and sampled the offshore Mississippi plume along its axis. In situ sampling in combination with remote sensing allowed us to estimate integrated plume primary productivity. Carbon fixation in the northern GOM averaged $0.53 \mu \mathrm{g} \mathrm{Cl}^{-1} \mathrm{~h}^{-1}$ for non-plume stations, and $9.3 \mu \mathrm{g} \mathrm{Cl}^{-1} \mathrm{~h}^{-1}$ in plume stations. We estimated integrated productivity of the plume at ca. $3.28 \times 10^{9} \mathrm{~g} \mathrm{C} \mathrm{h}^{-1}$, which accounted for 41 and $13 \%$ of all surface and total water column productivity in the oligotrophic GOM, respectively, at the time of sampling. Analysis of $r b c L$ cDNA clone libraries and HPLC pigment data indicated that our sampling transect traversed several regions with distinctly different phytoplankton assemblages. Non-plume communities were numerically dominated by Prochlorococcus, and contained prymnesiophytes and eustigmatophytes. Diatoms dominated the most productive inshore station, while Synechococcus dominated in the mid-plume just off the Louisiana shelf. The least productive and most offshore portion of the plume was also diatom dominated. Diatoms were the most diverse algal class observed, accounting for over $42 \%$ of all unique rbcL genotypes detected in the plume. Collectively, these results indicate that the Mississippi River plume contributes significantly to oligotrophic productivity in the GOM, resulting from localized blooms of both Synechococcus and diatoms.
\end{abstract}

KEY WORDS: Phytoplankton - Nutrients Gulf of Mexico - Gene regulation · Mississippi plume · RubisCO

Resale or republication not permitted without written consent of the publisher

\section{INTRODUCTION}

The Mississippi River is the 7th largest freshwater input into the world's oceans (Milliman \& Meade 1983), and strongly affects the biological productivity of the northern Gulf of Mexico shelf (Walsh 1988, Lohrenz et al. 1994, Redalje et al. 1994, Fahnenstiel et al. 1995, Rabalais et al. 2002). The region surrounding the Mississippi Delta is in fact so productive that it accounts for 70 to $80 \%$ of Gulf of Mexico (GOM) fishery landings (Lohrenz et al. 1999, Grimes 2001), the US portion, of which alone was valued at ca. \$994 million during the year 2000 (National Marine Fisheries Service pers. comm.). The forces controlling biological productivity and phytoplankton community composition in this region are thus of great ecological and economic interest.

On a basin-wide scale, phytoplankton distribution in the GOM has been studied using ocean color satellite images (Müller-Karger et al. 1991). Surface pigment concentrations on the Gulf of Mexico shelf are generally higher than those observed for the oligotrophic Gulf and peak during winter. Pigments also undergo a marked seasonal cycle strongly influenced by the depth of the mixed layer. In contrast, surface pigment concentrations in the oligotrophic portion of the Gulf are generally low and display little seasonality. The Mississippi River plume, which usually extends westward along 
the Louisiana and Texas coastline, is thought to be responsible for the high productivity of these waters. Particularly during the summer months, low salinity, high chlorophyll and highly productive water can also be carried southeastward into the oligotrophic GOM. Under these circumstances, in Sea-viewing Wide Fieldof-View Sensor (SeaWiFS) images, the plume appears as a conspicuous, high-chlorophyll surface feature stretching from the Mississippi River Delta across the Gulf as far as the Dry Tortugas (Müller-Karger et al. 1991, Perez et al. 1999, Wawrik et al. 2003). Often a second plume containing elevated surface chlorophyll originating from the Yucatan upwelling, joins the Mississippi River plume tracing and completely outlining the Loop Current. The Mississippi outflow westward of the Mississippi Delta has been studied intensely, in part because the plume has been implicated in the formation of extensive areas of hypoxic bottom water (Justic et al. 1996, Rabalais et al. 1996). Far less is known about the far-field effect of the Mississippi River plume in the oligotrophic GOM, where it can on occasion be a prominent feature. Little is known in particular about its impact on basin-wide primary production and phytoplankton community composition.

We have previously described the vertical structure of the picoplankton community at a site within the offshore Mississippi River plume (Wawrik et al. 2003). Using a combination of flow cytometry, mRNA hybridization, pigment analysis and rbcL (large subunit gene of ribulose-1,5-bisphosphate carboxylase/ oxygenase [RubisCO]) cDNA clone libraries, we demonstrated the vertical distribution of phytoplankton species in the water column. The plume harbored a large bloom of Synechococcus, which replaced Prochlorococcus in the upper water column, as determined by comparison with a nearby non-plume site. Our observations concerning a single site in the offshore Mississippi plume led us to the current investigation of the phytoplankton dynamics along a transect of the plume from the Louisiana shelf far into the oligotrophic Gulf of Mexico. Specifically, we were interested in determining if the phytoplankton community composition was dynamic and changed along the axis of the plume. Secondly, we wanted to determine the relative importance of the plume to surface water production of the Gulf of Mexico basin.

\section{MATERIALS AND METHODS}

Sampling. Sampling was performed aboard the RV 'F. G. Walton-Smith' in the NE Gulf of Mexico between July 15 and 23, 2001 (see Fig. 1 for station locations). Using SeaWiFS satellite images downloaded daily to the vessel, we determined the approximate location of the plume. The onboard auto-sampling system (which recorded near surface in situ fluorescence and salinity) was then used. We located the frontal boundary between the plume and the non-plume GOM. Stations were chosen some distance away from the frontal boundary, inside the plume, so that our stations formed a series that followed the length of the plume towards the Mississippi shelf. Station locations were as follows: Stn 1: $26^{\circ} 00^{\prime} \mathrm{N}, 83^{\circ} 35.6^{\prime} \mathrm{W}_{\text {; }}$ Stn $2: 27^{\circ} 17^{\prime} \mathrm{N}, 87^{\circ} 23^{\prime} \mathrm{W}$; Stn 3: $27^{\circ} 30^{\prime} \mathrm{N}, 88^{\circ} 24^{\prime} \mathrm{W}_{\text {; }}$ Stn $4: 27^{\circ} 58^{\prime} \mathrm{N}^{\prime} 87^{\circ} 35^{\prime} \mathrm{W}_{\text {; }}$ Stn 5: $28^{\circ} 33^{\prime} \mathrm{N}, 87^{\circ} 24.9^{\prime} \mathrm{W}_{\text {; }} \mathrm{Stn} 6$ : $28^{\circ} 59.9^{\prime} \mathrm{N}, 8^{\circ} 38.6^{\prime} \mathrm{W}_{\text {; }}$ Stn 7: $26^{\circ} 28.7^{\prime} \mathrm{N}, \quad 86^{\circ} 38.6^{\prime} \mathrm{W}_{i} \quad \mathrm{Stn}$ 8: $25^{\circ} 15.78^{\prime} \mathrm{N}$, $84^{\circ} 13.21^{\prime} \mathrm{W}$.

Before sampling, the conductivity temperature depth recorder (CTD) was cast to a depth of $200 \mathrm{~m}$ in order to determine the fluorescence profile in the water column and the depth of the subsurface chlorophyll maximum (SCM). For profiles, seawater was sampled from a total of 8 depths. Sampling depths were chosen so that 1 sample was taken immediately above, inside and immediately below the SCM. The near surface samples were taken at a depth of $3 \mathrm{~m}$ using a small electric impeller pump. The remaining samples were taken at depth spaced evenly throughout the euphotic zone. Sampling was performed during morning hours using 201 Niskin bottles attached to rosette sampler equipped with a Seabird CTD. Samples from greater than $40 \mathrm{~m}$ of depth were protected from light by wrapping carboys in black plastic bags during filling and sample processing.

${ }^{14} \mathrm{C}$-carbon fixation. ${ }^{14} \mathrm{C}$-carbon fixation was measured by a technique adopted from Carpenter \& Liveley (1980) in sterile, acid-cleaned $500 \mathrm{ml}$ polycarbonate flasks, assaying $325 \mathrm{ml}$ water samples. Flasks were incubated under irradiance, adjusted to resemble the intensity and spectral features of the underwater light field for $2 \mathrm{~h}$ using neutral-density screening and colored acetate filters. Depth profiles of irradiance intensity were determined using a Li-Cor light meter equipped with Li190SA and Li-192SA radiation sensors.

RNA extraction for RT-PCR. Between 200 and $800 \mathrm{ml}$ of seawater were filtered onto $25 \mathrm{~mm}, 0.45 \mu \mathrm{m}$ HV polyvinylidene difluoride filters (Millipore Durapore). Filters were then stored under liquid nitrogen in $2 \mathrm{ml}$ screw-cap tubes containing $750 \mu \mathrm{l}$ RLT buffer (Qiagen), $7.5 \mu \mathrm{l} \beta$-mercapto ethanol and $0.2 \mathrm{~g}$ muffled, baked glass beads. Samples were not treated with diethyl-pyrocarbonate (DEPC), as is commonly done for probing experiments, since DEPC inhibits RT-PCR reactions by chemically modifying RNA. For extraction, samples were thawed in warm water for $2 \mathrm{~min}$ and cell lysis was achieved by bead-beating as described previously (Wawrik et al. 2003). Lysate was then extracted using a Qiagen RNEasy RNA extraction kit (Qiagen). Samples were DNAse digested on the RNEasy columns for 15 min using the RNAse-free 
DNAse reagent set (Qiagen) according to the protocol provided by Qiagen for removing DNA contamination.

PCR. Reverse transcriptions were run using random hexamers, $4.7 \mathrm{mM} \mathrm{MgCl}$, and Moloney marine leukemiavirus (M-MLV) reverse transcriptase (Promega) for $30 \mathrm{~min}$ at $37^{\circ} \mathrm{C}$, and $5 \mu \mathrm{l}$ of freshly extracted RNA. Five $\mu \mathrm{l}$ were then added to a PCR reaction. Two primer sets were used to amplify the $r b c L$ fragments. The form IA/B primer set produced a $615 \mathrm{bp}$ fragment (forward primer: TCIGCITGRAACTAYGGTCG, reverse primer: CTGAGIGGIAARAACTACGG) and the form ID set produced a 554 bp fragment (forward primer: GATGATGARAAYATTAACTC, reverse primer ATTTGDCCACAGTGDATACCA). All sequences are stated using International Union of Pure and Applied Chemistry (IUPAC) degeneracies. PCR conditions were as follows: $1 \mu \mathrm{M}$ final concentration for both primers, $1.5 \mathrm{mM}$ $\mathrm{MgCl}_{2}, 2.5 \mathrm{mM}$ of each nucleotide and 5 units of TAQ polymerase (Promega). Cycle parameters were: $3 \mathrm{~min}$ at $95^{\circ} \mathrm{C}$ followed by 40 cycles of $1 \mathrm{~min}$ at $95^{\circ} \mathrm{C}, 1 \mathrm{~min}$ at $52^{\circ} \mathrm{C}$ and $1 \mathrm{~min} 30 \mathrm{~s}$ at $72^{\circ} \mathrm{C}$. Cycling was followed by a $15 \min 72^{\circ} \mathrm{C}$ elongation step.

Clone libraries. $r b c L$ mRNA was RT-PCR amplified from the surface samples of all 8 stations using both primer sets. Immediately after amplification, products were purified using the Qiaquick PCR purification kit (Qiagen). Amplicons were then ligated into $\mathrm{pCR}^{\circledR} 2.1$ vector using a TA cloning kit (Invitrogen). All white colonies were then picked onto individual $2 \mathrm{x}$ yeast tryptone (YT) plates containing $50 \mu \mathrm{g} \mathrm{ml}^{-1}$ kanamycin and ampicillin. The number of clones picked for Stns 1 through 8 were $40,37,43,39,41,43,42$ and 45 , respectively, for the form ID primer set, and 39, 40, 40, 39, 40, 30,38 and 39, respectively, for the form IA/B primers. Clones were screened for the correct insert size using PCR by touching a colony with a sterile loop and transferring this loop directly to a PCR reaction tube. The number of colonies with correct insert sizes from Stns 1 through 8 for the form ID primers set were 30, 13, 33, $38,35,36,28$ and 37 , respectively, and 21, 32, 30, 17, 17 , 10,17 , and 16 for the form IA/B primers. Amplifications with products of the correct size were purified up using a QIAquick PCR purification kit (Qiagen). Twenty $\mu \mathrm{l}$ of purified product were then digested with 5 units of each Sau3IA (digests at ${ }^{\downarrow}$ GATC $\uparrow$ ) and AluI (digests at $\mathrm{AG}^{\downarrow} \uparrow \mathrm{CT}$ ) in Buffer B (Promega) for $1 \mathrm{~h}$ at $37^{\circ} \mathrm{C}$. Digestions were run on $2.5 \%$ low-melting agarose gels (Fisher) at $13.5 \mathrm{~V} \mathrm{~cm}^{-1}$ for $2 \mathrm{~h}$ and stained with ethidium bromide. Clones with unique restriction patters were visually selected for sequencing. We performed sequencing in an Applied Biosystems model 373 sequencer at the University of Florida core sequencing laboratory (University of Florida, Gainesville, FL).

Phylogenetic analysis. DNA sequences were translated into amino acids and translations were aligned with a representative sample of $r b c L$ sequences obtained from GenBank as were all sequences we recovered previously from similar environments (Paul et al. 2000, Wawrik et al. 2003). Alignment was performed using Omiga 1.1 (Oxford Molecular Group) using a Clustal W pairwise-weighted alignment method. Amino acid sequences were used instead of DNA sequences to generate phylogenetic trees in order to avoid potential biases introduced by codon usage and GC content. Alignments were inspected for obvious misalignments, and exported to Mega 2.0 beta (Kumar et al. 1993). Trees were built using both parsimony and the neighbor-joining (NJ) methods. For NJ trees, a gamma distribution (gamma parameter $=2.0$ ) was used to correct for rate heterogeneity across sites. Accession numbers for the clones obtained here are as follows: AY157365-AY157486.

Plume area and productivity estimates. A $7 \mathrm{~d}$ composite of level 3 SeaWiFS images was used. The image was imported into a graphics editor, the plume was outlined by hand and then shaded in white. All non-plume pixels were shaded black and all white pixels were then counted by importing the image into Matlab (Mathworks). Level 3 SeaWiFS images are mapped to a resolution of 1 by $1.1 \mathrm{~km}$ so that the area estimate can be derived. In a similar fashion, an area estimate for the total oligotrophic Gulf of Mexico (oGOM) as well as the eastern portion of the oGOM, bounded by the tip of Yucatan, Key West and the Mississippi Delta, was obtained. For productivity estimates, we divided the plume longitudinally into sections bounded by the longitudinal midpoints between our stations. The area for each section was then estimated individually and productivity was extrapolated from the individual stations located with the sections assuming a plume thickness of $10 \mathrm{~m}$. Stn 8 was an oligotrophic station and served as the productivity baseline. Water column productivity was integrated for $1 \mathrm{~m}^{2}$ of surface ocean as follows: The water column was divided into segments bounded by the surface, the half-way points between each pair of adjacent sampling depth and the depth of the bottom sample. Primary productivity measurements taken within each interval were then extrapolated to the volume of the segment, and all estimates for the water column segments were then added.

Statistical analysis of the community data. The community data (see Table 3) was imported into the PRIMER software package (Primer-E) and normalized so that relative numbers (percentages) of total abundance were obtained. A square root transformation was applied to the normalized community data matrix and a dissimilarity matrix was calculated using BrayCurtis dissimilarity coefficients. The resulting triangular dissimilarity matrix was used as the basis for clustering and multi-dimensional scaling (MDS) analysis.

In order to test if there was significant genetic overlap between the libraries from individual sampling 
sites pairwise F-tests (Martin 2002) were performed. For F-test analysis, all sequences were first aligned and alignments for individual stations were imported into Arlequin (http://anthro.unige.ch/arlequin) as individual populations while a frequency of 1 for each unique sequence and setting alpha to 0.05 . To test if individual libraries contained distinct phylogenetic lineages we performed pairwise $P$-tests (Martin 2002). For $P$-test analysis, a best possible tree is generated from an alignment of all clones sampled from 2 communities. A single character representing the sampling site is then mapped to this tree and its parsimony length is calculated. This length is then compared to a histogram of 1000 randomly rearranged trees. This analysis was performed in Phylogenetic Analysis Using Parsimony (PAUP) (Sinauer Associates).

Contour plots. CTD profiles were first exported from Seasave v.5.21f (Seabird Electronics) at a density of 1 data point $\mathrm{s}^{-1}$. This produced profiles with a data density slightly higher than 1 data point $\mathrm{m}^{-1}$ depth. The data series were then trapezoidally splined in Matlab (Mathworks) to a density of 1 data point $\mathrm{m}^{-1}$, in order to obtain the same spacing for all profiles. Contour plots were then generated using the Kriging method in Sigmaplot (SPSS).

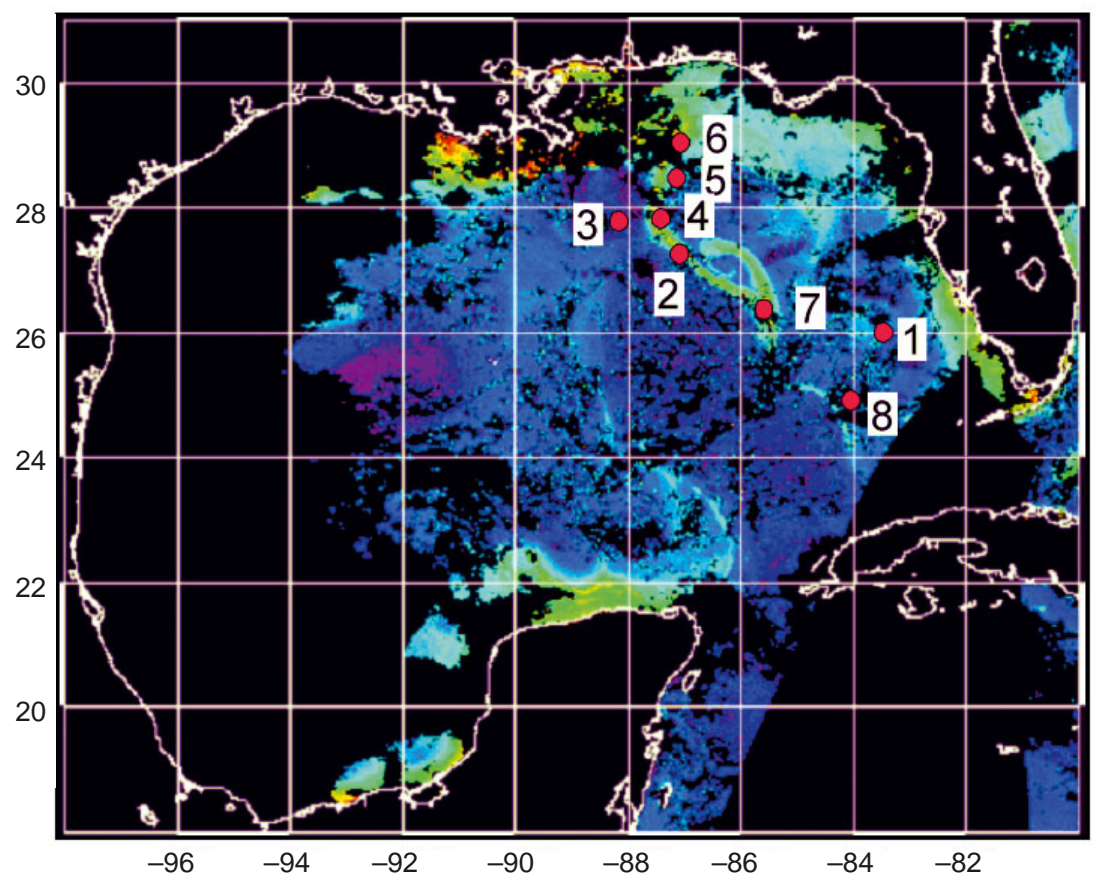

Fig. 1. Surface chl a concentrations in the NE Gulf of Mexico derived using the SeaViewing Wide Field-of-View Sensor (SeaWiFS). Lighter colors indicated higher amounts of colored material in surface water. Concentrations near the Mississippi River Delta and in the river plume, as well as in other coastal areas, are subject to known effects by high concentrations of colored dissolved organic matter, suspended sediments, or bottom reflectance, which can artificially raise chl a estimates. Land and clouds are colored black. Station locations are indicated
Pigment analysis. Four 1 of seawater were filtered in duplicate through $2.5 \mathrm{~cm}$ Whatman GF/F glass fiber filters. Filters were wrapped in aluminum foil, frozen in liquid nitrogen and stored at $-80^{\circ} \mathrm{C}$ until processing. Samples were extracted with acetone for analysis (Millie et al. 1993). The contribution of diatoms to bulk fucoxanthin and chl a was estimated using previously published pigment ratios. Pelagophytes and haptophytes fucoxanthin was subtracted from bulk fucoxanthin by using a fucoxanthin-to-19-hexanol-oxyfucoxanthin ratio of 0.02 and a fucoxanthin to 19-butanoyl-oxyfucoxanthin ratio of 0.14 (Letelier et al. 1993). For diatom chl a estimates, we used a chl a:fucoxanthin ratio of 0.8 (Claustre et al. 1994). Estimate of the contribution of Synechococcus to total chl a were obtained as described by Morel (1997). A concentration of $2 \mathrm{fg}$ chl a per Synechococcus cell counted by flow-cytometry was assumed as this value represents a typical concentration under growthsaturating irradiance (Kana \& Glibert 1987).

\section{RESULTS}

During July of 2001 the Mississippi River plume was carried into the eastern oligotrophic Gulf of Mexico (Fig. 1) causing a substantial phytoplankton bloom detected by SeaWiFS ocean color imagery. Using these remote sensing images, the plume was estimated to cover an area of $33470 \mathrm{~km}^{2}$, accounting for ca. 9.16 and $2.75 \%$ of the surface area of the NE and total oligotrophic GOM, respectively. Our sampling transect of this feature began on the west Florida shelf and proceeded along the approximate plume axis towards the Mississippi River Delta. A total of 8 profiles were sampled at the stations shown in Fig. 1. Stn 1 was on the west Florida shelf and was not associated with the Mississippi plume, but nonetheless displayed slightly lower salinity (34.8 ppt, Table 1) than is typical for the offshore Gulf of Mexico (ca. 36.1 ppt, see Stn 8, Table 1). Stn 1 also exhibited slightly elevated surface chlorophyll as seen in SeaWiFS images (data not shown). Stn 8 was a station typical of the oligotrophic conditions found in the southeast GOM. Stns 7, 2, 3, 4, 5 and 6 were a series of stations located along the approximate axis of the plume and progressively closer to the Mississippi River Delta. Stn 3 was our most west- 
Table 1. Surface salinity as measured by the onboard auto sampling system, rate of carbon fixation measured in surface samples and rate of integrated water column carbon fixation

\begin{tabular}{|cccc|}
\hline Stn & $\begin{array}{c}\text { Salinity } \\
(\mathrm{ppt})\end{array}$ & $\begin{array}{c}\text { Carbon fixation } \\
\left(\mu \mathrm{g} \mathrm{h}^{-1} \mathrm{l}^{-1}\right)\end{array}$ & $\begin{array}{c}\text { Integrated water } \\
\text { column production } \\
\left(\mathrm{g} \mathrm{h}^{-1} \mathrm{~m}^{2}\right)\end{array}$ \\
\hline 1 & 34.79 & 0.654 & na \\
2 & 34.73 & 7.69 & 0.10 \\
3 & 34.29 & 7.7 & na \\
4 & 31.50 & 10.12 & na \\
5 & 31.97 & 8.71 & na \\
6 & 30.84 & 16.19 & 0.27 \\
7 & 33.48 & 5.5 & 0.097 \\
8 & 36.05 & 0.4 & 0.040 \\
\hline
\end{tabular}

ward station and may have been located in a small eddy seen in sea-surface color images at the western margin of the plume.

Carbon fixation at non-plume stations averaged 0.53 and $9.3 \mu \mathrm{g} \mathrm{C} \mathrm{l}^{-1} \mathrm{~h}^{-1}$ in the plume stations (Table 1). Using these in situ measurements as a basis for extrapolation, we estimated that integrated productivity of the plume was ca. $3.28 \times 10^{9} \mathrm{~g} \mathrm{C} \mathrm{h}^{-1}$. Given our measurements of surface productivity at Stn 8, our oligotrophic non-plume reference site, we calculated that the plume accounted for as much as $41 \%$ of all carbon fixation in the upper $10 \mathrm{~m}$ of the oligotrophic GOM. Similar calculations also indicate that the plume may have accounted for as much as $71 \%$ of all surface production occurring in its NE portion of the GOM. Our sampling strategy allowed for the estimation of integrated water column productivity at 4 stations (not enough data were available at the remaining sites). Integrated productivity ranged between 0.04 and $0.27 \mathrm{~g} \mathrm{C} \mathrm{h}^{-1} \mathrm{~m}^{-2}$. Production was lowest at Stn 8, our most oligotrophic station, and highest at Stn 6, the most inshore plume profile.

The plume also influenced productivity in the lower water column below the plume. Stns 4 and 6 had no discernable SCM, and productivity below the plume was minimal at these stations (data not shown). The SCM at Stn 3 was similar to a typical oligotrophic profile, but SCM productivity $\left(0.33 \mu \mathrm{g} \mathrm{C}^{-1} \mathrm{~h}^{-1}\right)$ was only ca. $15 \%$ of the rate measured at the SCM of Stn 1 (2.13 $\left.\mu \mathrm{g} \mathrm{C}^{-1} \mathrm{~h}^{-1}\right)$ and only ca. $67 \%$ of the rate in our sample from Stn 8 (0.495 $\mu \mathrm{g} \mathrm{C}^{-1} \mathrm{~h}^{-1}$ ). No data were available for the SCM of Stn 5. Stn 2 displayed a broad, poorly defined SCM between 50 and $100 \mathrm{~m}$ depth. Productivity in this feature was similar to values

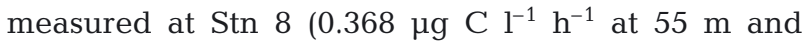
$0.587 \mu \mathrm{g} \mathrm{Cl}^{-1} \mathrm{~h}^{-1}$ at $100 \mathrm{~m}$ depth) but only 17 to $27 \%$ of the rate at Stn 1 . It should be noted that the SCM sample obtained at Stn 8 was taken ca. $8 \mathrm{~m}$ above the actual peak in in situ fluorescence (data not shown). The carbon fixation rate measured in this sample may consequently be a considerable underestimate of productivity at the true SCM. This assumption is supported by data previously collected in our sampling area (Wawrik et al. 2003). Productivity at the SCM of Stn 5 (2.03 $\mu \mathrm{g} \mathrm{C} \mathrm{l}^{-1} \mathrm{~h}^{-1}$ ) during our 1999 cruise was considerably higher than our measurements at Stn 8.

Elevated surface pigment concentrations observed by SeaWiFS were corroborated by in situ observations. Surface fluorescence, as measured by the onboard auto-sampling system, increased 11-fold from 0.13 fluorescence units (FU) at Stn 8 to $1.45 \mathrm{FU}$ at Stn 4 . Fig. 2A shows a composite contour plot of the fluores-
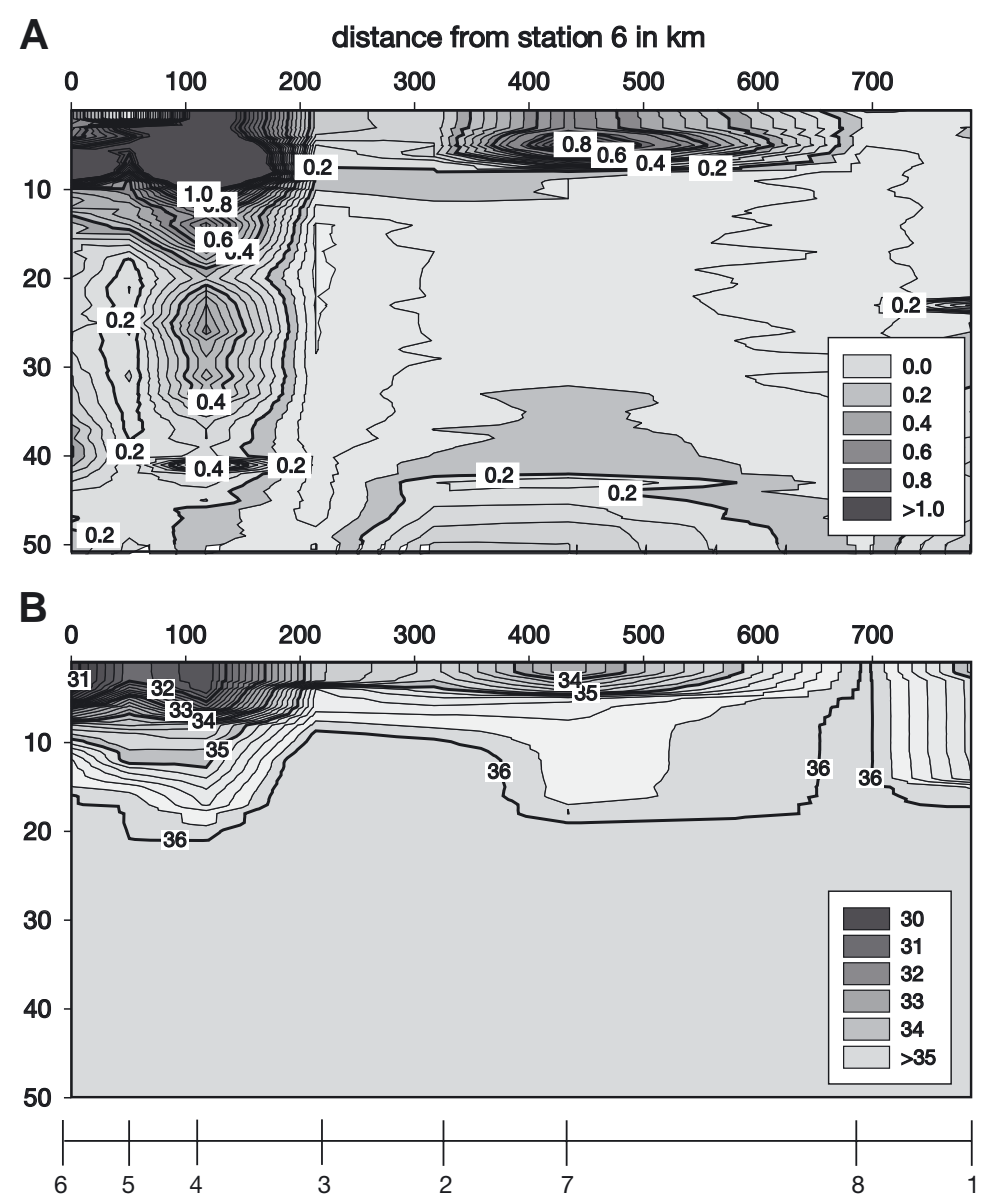

Fig. 2. (A) In situ fluorescence in the upper $50 \mathrm{~m}$ of the water column along the plume transect as measured during the CTD casts. Darker colors indicate higher fluorescence. Units are FU (fluorescence units) indicated by the CTD instrument. (B) Salinity in the upper $50 \mathrm{~m}$ of the water column along the plume transect as measured during the CTD casts. Lighter colors indicate higher salinity 
Table 2. Pigment concentrations in surface samples along our transect. Data were obtained by HPLC analysis. Also shown are data obtained by pigment analysis. Shown are the \% fucoxanthin accounted for by diatoms and the \% chl a accounted for by diatoms, Synechococcus and other phytoplankton. Fucox.: fucoxanthin; 19'-hex: 19'-hexanoyl-oxyfucoxanthin; 19'-but: 19'-butanoyl-oxyfucoxanthin; zeax: zeaxanthin

\begin{tabular}{|c|c|c|c|c|c|c|c|c|c|c|}
\hline Stn & $\begin{array}{l}\text { Chl a } \\
\left(\mu \mathrm{g} \mathrm{l}^{-1}\right)\end{array}$ & $\begin{array}{l}\text { Fucox. } \\
\left(\mu g \mathrm{l}^{-1}\right)\end{array}$ & $\begin{array}{c}\text { Chl b } \\
\left(\mu g l^{-1}\right)\end{array}$ & $\begin{array}{l}19^{\prime} \text {-hex } \\
\left(\mu g \mathrm{l}^{-1}\right)\end{array}$ & $\begin{array}{l}19^{\prime} \text {-but } \\
\left(\mu g \mathrm{l}^{-1}\right)\end{array}$ & $\begin{array}{l}\text { Zeax. } \\
\left(\mu g \mathrm{l}^{-1}\right)\end{array}$ & $\begin{array}{c}\text { Fucox. due } \\
\text { to diatoms } \\
\qquad(\%)\end{array}$ & $\begin{array}{l}\text { Chl a due to } \\
\text { diatoms } \\
(\%)\end{array}$ & $\begin{array}{c}\text { Chl a due to } \\
\text { Synechococcus } \\
(\%)\end{array}$ & $\begin{array}{c}\text { Chl a due to } \\
\text { other phytoplankton } \\
(\%)\end{array}$ \\
\hline 1 & 0.276 & 0.0136 & 0.0101 & 0.0280 & 0.0067 & 0.0482 & 92.7 & 3.94 & 25.30 & 70.76 \\
\hline 2 & 1.089 & 0.278 & 0.0102 & 0.0702 & 0.0102 & 0.0776 & 99.4 & 20.46 & 5.14 & 74.44 \\
\hline 3 & 1.74 & 0.0845 & 0.0073 & 0.0721 & 0.0161 & 0.601 & 97.2 & 3.88 & 10.42 & 85.72 \\
\hline 4 & 0.220 & 0.0128 & 0.0935 & 0.0206 & 0.0176 & 0.0065 & 80.3 & 4.64 & 56.37 & 38.96 \\
\hline 5 & 1.62 & 0.195 & 0.0453 & 0.148 & 0.0206 & 0.288 & 98.4 & 9.64 & 28.96 & 61.36 \\
\hline 6 & 1.99 & 1.14 & 0.0268 & 0.0813 & 0.0199 & 0.0825 & 99.7 & 45.81 & 8.11 & 46.09 \\
\hline 7 & 0.660 & 0.298 & 0.0121 & 0.0601 & 0.0076 & 0.0575 & 99.6 & 36.14 & 9.04 & 54.86 \\
\hline 8 & 0.250 & 0.0042 & 0.0075 & 0.0165 & 0.0033 & 0.0526 & 88.2 & 1.34 & 16.26 & 82.36 \\
\hline
\end{tabular}

cence values, measured during our CTD casts, as a function of depth and distance from the most inshore station (Stn 6). Salinity in this same transect ranged from $36.1 \mathrm{ppt}$ in the non-plume station (Stn 8) to 30.9 ppt at the most inshore site (Stn 6). A composite contour plot of the in situ salinity is shown in Fig. 2B. A low-salinity surface lens containing elevated in situ fluorescence extended more than $500 \mathrm{~km}$ into the oligotrophic Gulf of Mexico.

Pigment concentrations were determined by HPLC analysis (Table 2) and the increase in in situ fluorescence detected along the axis of the plume was re-
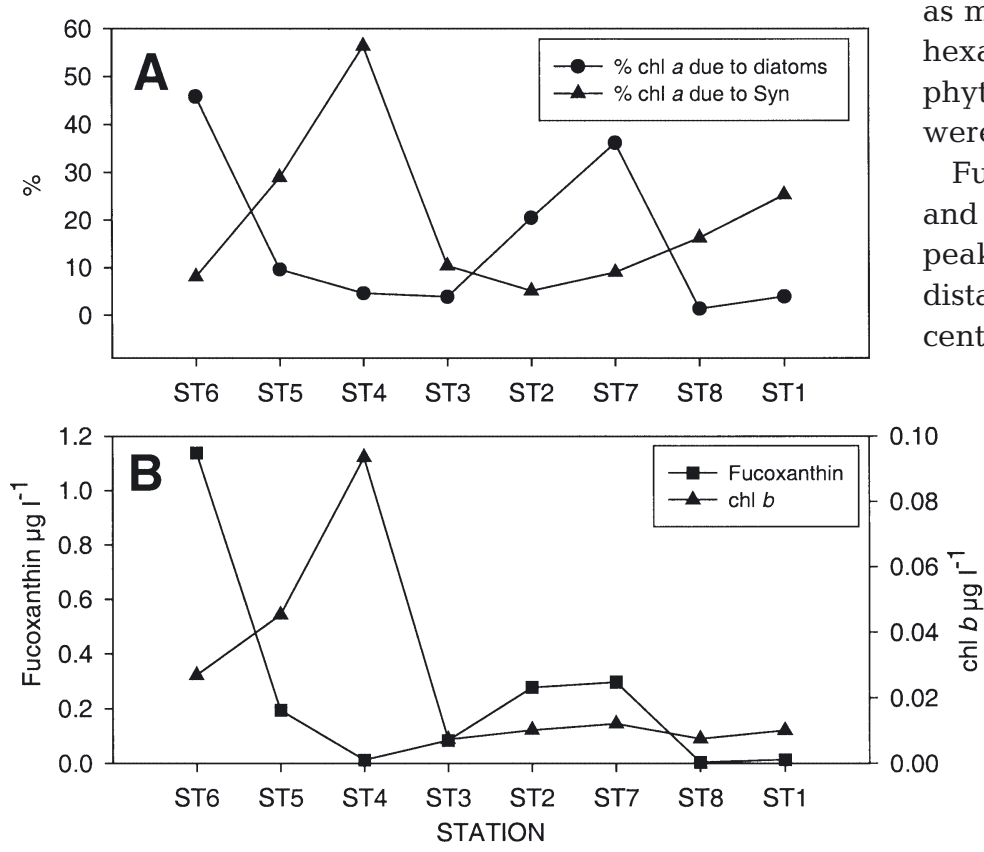

Fig. 3. Pigment data. (A) Estimation of contribution to bulk chl a by

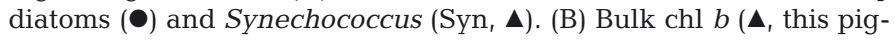
ment is diagnostic for chlorophytes) and fucoxanthin $(\mathbf{\square}$, indicative of diatoms, pelagophytes and haptophytes) flected in chl a measurements. Chl a was found to steadily increase from $0.25 \mathrm{\mu g} \mathrm{l}^{-1}$ at Stn 8 to $1.99 \mu \mathrm{g} \mathrm{l}^{-1}$ at our most inshore plume site (Stn 6). Chl $b$ (a diagnostic pigment for Chlorophyceae, Prasinophyceae and Euglenophyceae) was present at measurable quantities at all stations increasing from $0.027 \mu \mathrm{g}^{-1}$ at Stn 6 to a maximum of $0.094 \mu \mathrm{g} \mathrm{l}^{-1}$ at Stn 4 . Chl $b$ concentrations were low in the offshore portions of the plume (Stns 2, 3 and 7), where they were not significantly elevated over non-plume surface concentrations (Fig. 3B). The distribution of zeaxanthin was bimodal, exhibiting peaks at Stns 5 and 3 corresponding to the respective peaks in the abundance of Synechococcus and Prochlorococcus as measured by flow cytometry (data not shown). 19' hexanoyl-oxyfucoxanthin (diagnostic for prymnesiophytes) levels were highest at Stn $5\left(0.148 \mu \mathrm{g} \mathrm{l}^{-1}\right)$ and were elevated in most plume samples.

Fucoxanthin concentrations ranged between 0.004 and $1.14 \mu \mathrm{g} \mathrm{l}^{-1}$ displaying a bimodal distribution with peaks at Stn 6 (our most inshore plume station) and the distal plume Stns 2 and 7 (Table 2, Fig. 3B). Concentrations were lowest at Stn 4 and in non-plume samples. Since fucoxanthin is not only found in diatoms but also present in prymnesiophytes, chrysophytes and raphidophytes, a pigment algorithm was used to estimate the diatom derived fraction of this pigment. Diatoms clearly dominated the fucoxanthin pool accounting for more than $80 \%$ of this pigment at every station sampled. An analogous pigment algorithm was used to calculate the contribution of diatoms and Synechococcus to total chl a (Table 2, Fig. 3A). Synechococcus was most prominent at Stns 4 and 5, while diatoms accounted for a larger percentage of total chl $a$ at plume Stns 6, 2 and 7. Except at Stn 3, where both diatoms and Synechococcus were only minor contributors to $\mathrm{chl}$ a $(<15 \%$ 


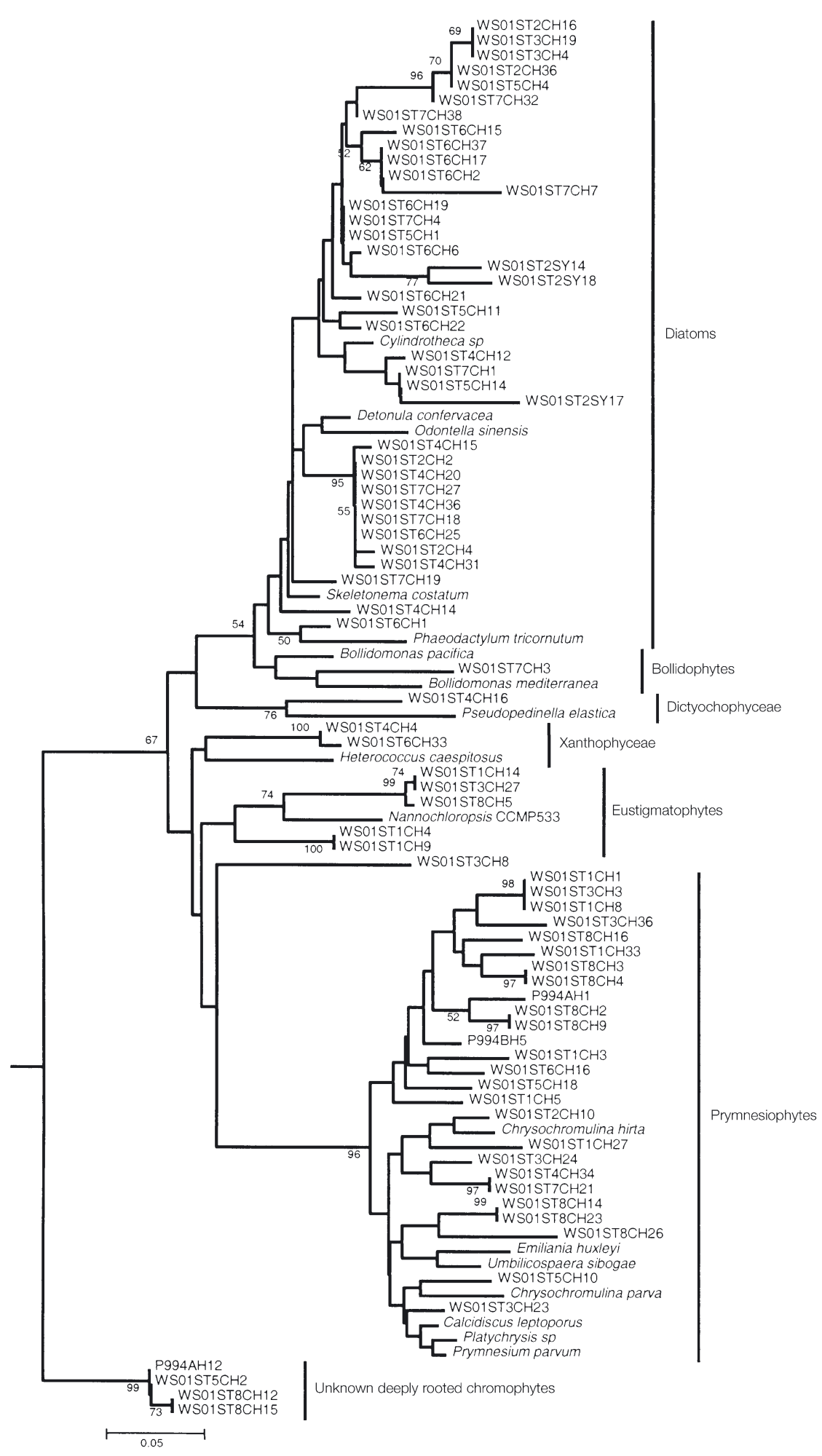

Fig. 4. Neighbor-joining bootstrap consensus tree obtained from an analysis of the derived amino acid sequences of all form ID sequences obtained here and their closest match in GenBank. Outgroup to the shown clade were several form IB and 1 form II (Gonyaulax polyedra) sequences. Numbers at internal nodes indicate bootstrap values obtained from 1000 bootstrap replicates combined), diatoms appeared most prominent where Synechococcus was least abundant.

Using molecular cloning of RT-PCR amplified $r b c L$ mRNA, we recovered 116 unique $r b c L$ sequences from the 8 surface samples, and their phylogenetic affiliations are shown in Figs. 4 \& 5. Most importantly, we observed that the bulk of the eukaryotic, autotrophic picoplankton in our sampling region was composed of diatoms (36 clones), prymnesiophytes (24 clones) and an array of sequences closely related to a diverse group of green algae (25 clones). Together these 3 algal groups accounted for $73 \%$ of the species richness observed. The remaining sequences included 6 eustigmatophytes, 9 prochlorophytes, 5 silicoflagellates, 2 sequences related to Trichodesmium thiebautii, 3 deeply rooted haptophytes and 1 sequence most closely related to the recently described bolidophytes (Guillou et al. 1999a,b). With the exception of the 2 Trichodesmium-like sequences, all form IB clones were related to chlorophytes and no other form IB cyanobacteria were found in our libraries. Form IA containing cyanobacteria (hereafter referred to as alpha-cyanobacteria) belonged either to the marine A cluster of Synechococcus, or the high-light adapted clade of Prochlorococcus. A breakdown of our libraries by station and algal group is shown in Table 3 .

Using the data shown in Table 3, a clustering analysis was performed to investigate the spatial patterns of community change in our sampling region. In such an analysis, sites with similar community composition form 'clades' of a dendogram. Fig. 6 shows the resulting dendogram. The same dendogram was obtained from an untransformed, a root or a double root transformed community data matrix. Three clusters of sites were obtained in this analysis. Based on results of our pigment analysis and our sampling strategy, these were labeled 'Non-Plume' (Stns 1, 3 and 8), 'Diatom Plume' (Stns 2, 6 and 7 ) and 'Synechococcus Plume' (4 and 5) respectively. To test the statistical significance of this division, several non-parametric analyses were performed. The ANOISM function of Primer (the software package used for the cluster analysis) indicated that the plume (diatom and/or Synechococcus) 


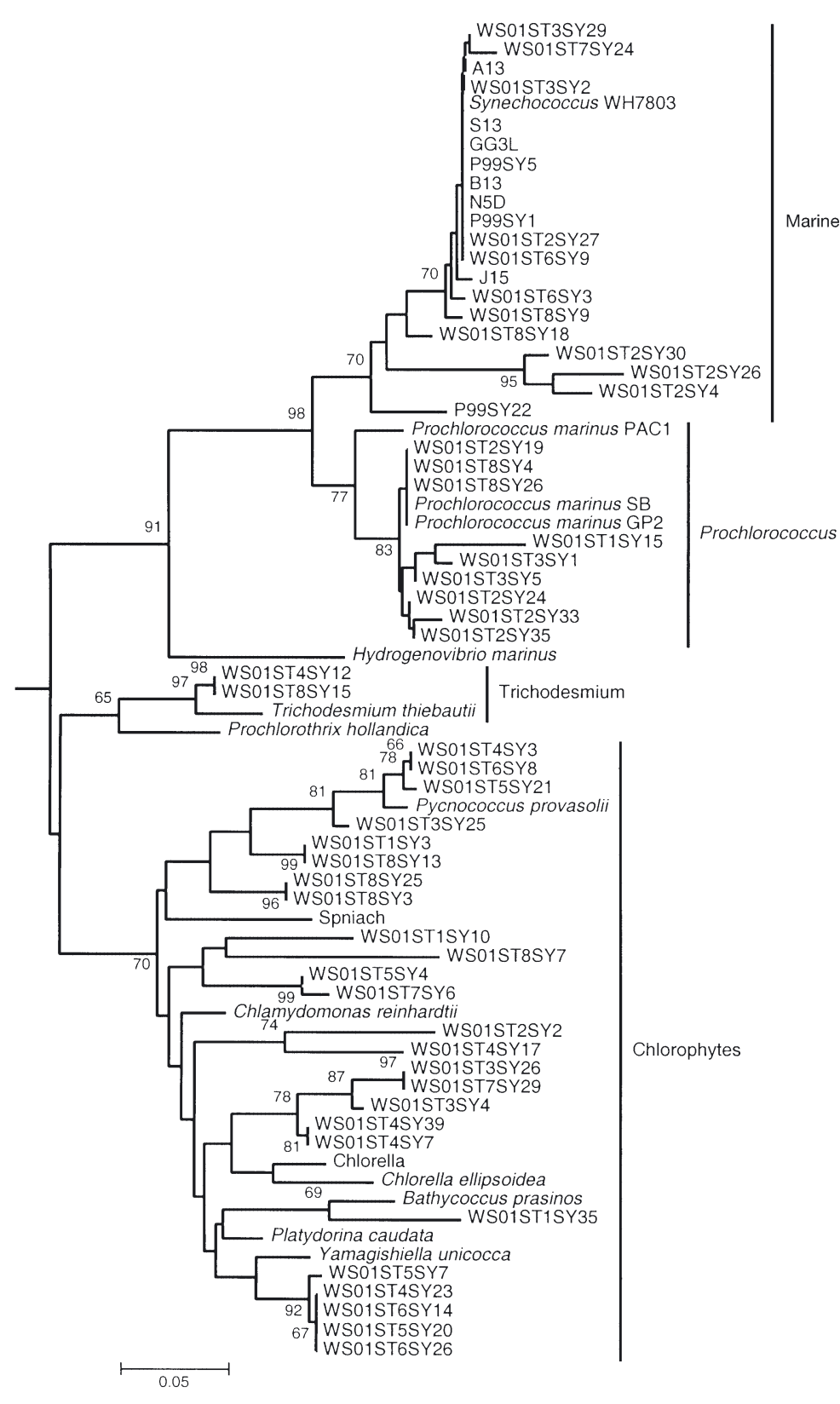

Fig. 5. Neighbor-joining bootstrap consensus tree obtained from an analysis of the derived amino acid sequences of all form IA and form IB sequences obtained here and their closest match in Genbank. Outgroup to the shown clade were several form ID and 1 form II (Gonyaulax polyedra) sequences. Numbers at internal nodes indicate bootstrap values obtained from 1000 bootstrap replicates

contained a community significantly different from 'Non-plume' sites $(\mathrm{R}=0.805$, significance level $=1.8 \%$, global $\mathrm{R}=1$ ). The same analysis also indicated that the 'Synechococcus plume' contained a community significantly different from the 'Diatom plume' at the $10 \%$ confidence interval $(R=0.917$, global $R=1)$. Analogous results were obtained by direct analysis of sequence information contained in our libraries by $F$ - and $P$-test analysis (Martin 2002). A significant $F$-test indicates less genetic diversity within individual communities (here sampling sites) than for both communities combined. A significant $P$-test indicates that the 2 communities that are being compared contain distinct phylogenetic lineages. $F$ - and $P$-tests were significant comparing 'Synechococcus' and 'Diatom plume' both individually or combined to 'Non-plume' sites at the $95 \%$ confidence interval. The F-test comparing 'Synechococcus' and 'Diatom' plume samples were also significant at the $10 \%$ confidence interval. Pairwise $F$ - and $P$-tests were also performed for all individual stations, and the resulting matrix is shown in Table 4. 'Synechococcus plume' stations were characterized by a high abundance of Synechococcus, as determined by flow cytometry (data not shown) and high nitrate levels (i.e. a high $\mathrm{N}$ to $\mathrm{P}$ ratio), while diatom dominated stations were characterized by lower $\mathrm{N}$ to $\mathrm{P}$ ratios (Wawrik et al. 2004, this issue).

As suggested by Martin (2002), we also generated 'Time-Versus-Lineage' plots for all 8 stations (Fig. 7). Notable is the right-shift of Stns 4 and 5 in this plot, indicating an excess of closely related sequences in our libraries from these stations (Martin 2002).

Table 3. rbcL cDNA library data. Indicated are the number of clones that were recovered for each phytoplankton taxonomic group and station

\begin{tabular}{|c|c|c|c|c|c|c|c|c|c|c|c|}
\hline Stn & $\begin{array}{l}\text { No. of unique } \\
\text { clones obtained }\end{array}$ & $\begin{array}{l}\text { Synecho- } \\
\text { coccus }\end{array}$ & $\begin{array}{l}\text { Tricho- } \\
\text { desmium }\end{array}$ & $\begin{array}{l}\text { Prymnesio- } \\
\text { phytes }\end{array}$ & $\begin{array}{c}\text { Eustigmato- } \\
\text { phytes }\end{array}$ & $\begin{array}{c}\text { Deeply rooted } \\
\text { haptophytes }\end{array}$ & Diatoms & $\begin{array}{l}\text { Prochloro- } \\
\text { coccus }\end{array}$ & $\begin{array}{l}\text { Bolido- } \\
\text { phytes }\end{array}$ & $\begin{array}{l}\text { Chloro- } \\
\text { phytes }\end{array}$ & $\begin{array}{l}\text { Silicoflag- } \\
\text { ellates }\end{array}$ \\
\hline 1 & 16 & - & - & 6 & 3 & - & - & 1 & - & 3 & 3 \\
\hline 2 & 17 & 4 & - & 1 & - & - & 7 & 4 & - & 1 & - \\
\hline 3 & 15 & 2 & - & 4 & 1 & - & 2 & 2 & - & 3 & 1 \\
\hline 4 & 12 & - & 1 & 1 & - & - & 5 & - & - & 5 & - \\
\hline 5 & 11 & - & - & 2 & - & 1 & 4 & - & - & 4 & - \\
\hline 6 & 15 & 2 & - & 1 & - & - & 9 & - & - & 3 & - \\
\hline 7 & 13 & 1 & - & 1 & - & - & 8 & - & 1 & 2 & - \\
\hline 8 & 21 & 2 & 1 & 8 & 1 & 2 & - & 2 & - & 4 & 1 \\
\hline
\end{tabular}




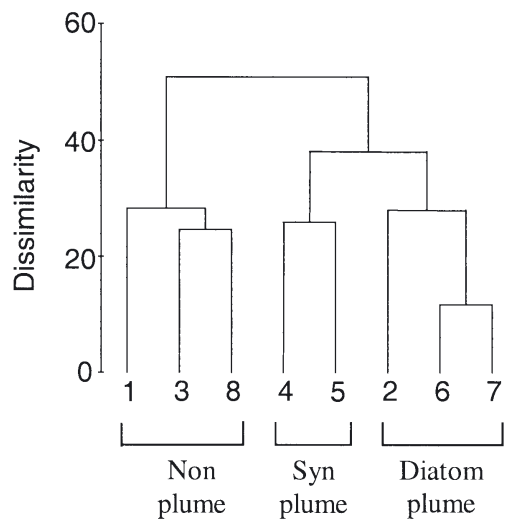

Fig. 6. Tree resulting from cluster analysis of the community data. The tree was generated from a Bray-Curtis dissimilarity matrix. The individual clades were labeled non-plume, young plume and declining plume, respectively, based on their geographic location. Numbers are station numbers (Stns 1-8)

Table 4. Pairwise matrix of $F$ - and $P$-test results. Upper right half of matrix indicates significant (+) and non-significant (-) F-test results. Lower left half indicates $P$-test results. Numbers are station numbers (Stns 1-8)

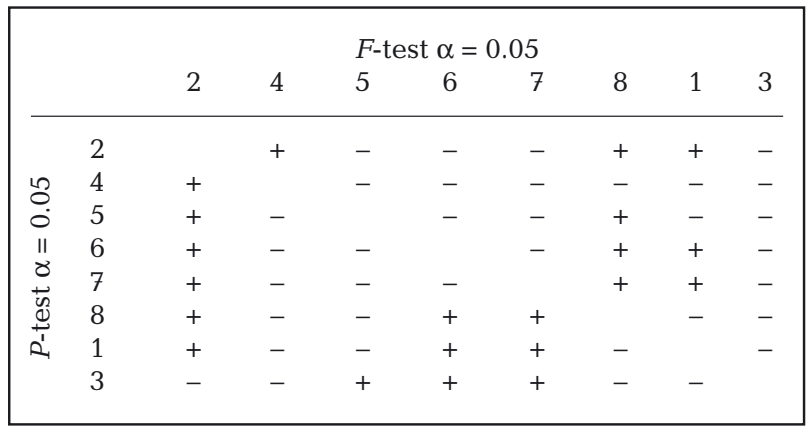

\section{DISCUSSION}

The Mississippi River drains approximately $40 \%$ of the continental United States (Moody 1967) and is the dominant source of new nutrients to the northern GOM. These nutrients lead to enhancement of productivity in the delta region. Although the importance of the river to productivity of the northern GOM has long been recognized (Riley 1937, Fox et al. 1987, Lohrenz et al. 1990, 1997, Chin-Leo \& Benner 1992, Pakulski et al. 1995, Rabalais et al. 1996), many details of the biological processes linked to it are still not well understood. Remote sensing in combination with targeted sampling of the offshore Mississippi River plume allowed us to sample this feature without a basin-wide shipboard sampling program. Using a combination of in situ data and image analysis of remote sensing data, we estimated integrated plume primary productivity.
We also surveyed the ambient phytoplankton populations at several stations within and outside the plume using molecular techniques and pigment analysis.

Our estimates of plume surface-layer productivity dramatically illustrate the importance of the Mississippi River plume to productivity in the GOM. Integrated estimates revealed that as much as 41 and $71 \%$ of all surface productivity in the oligotrophic GOM (total and northeastern portion respectively) were directly linked to productivity in the Mississippi plume, at least during July of 2001. These estimates confirm and upwardly modify similar estimates previously reported by our group (Wawrik et al. 2003). This previous study, however, relied on just 1 station with characteristics most similar to those of Stn 7, our plume station most distant from the delta (salinity $=33.5 \mathrm{ppt}$,

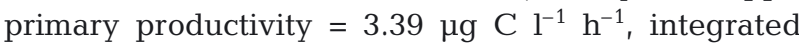
productivity $=63.1 \mathrm{mg} \mathrm{C} \mathrm{h}^{-1} \mathrm{~m}^{-2}$ ). The more productive regions of the plume were not sampled during the 1999 cruise and we believe that estimates presented here are more representative and accurate.

In a previous study, we had hypothesized that productivity at the SCM of some plume-associated sites may in fact be reduced and that total water column productivity can in some cases be lowered due to light attenuation by the plume (Wawrik et al. 2003). Data presented here partially confirms this hypothesis. Productivity as well as its ratio to chl a (data not shown) in SCM plume samples was clearly influenced and reduced by the presence of the plume. A depression in total water column productivity due to presence of the plume however was not supported by our data. Stns 2 ,

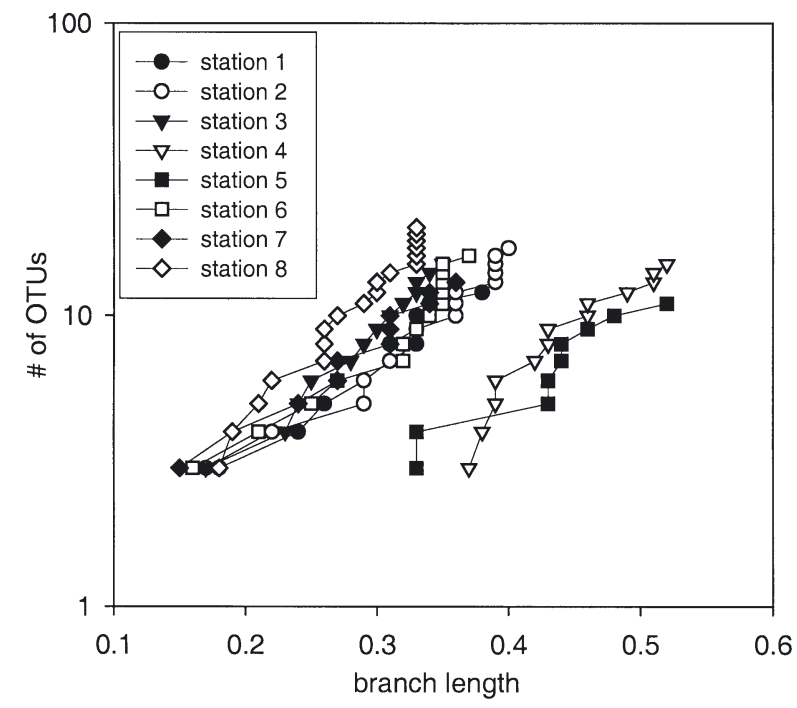

Fig. 7. Time versus lineage plots for all 8 stations generated from neighbor-joining consensus trees assuming a molecular clock. Time intervals were of equal length and the time unit was arbitrarily defined as 0.1 . OTU: operational taxonomic unit 
6 and 7 all displayed substantially greater integrated productivity than Stn 8 (not enough data were available to integrate other stations). Productivity at these stations was also higher than at both stations sampled during our 1999 cruise (Wawrik et al. 2003), non-plume $=0.083 \mathrm{~g} \mathrm{C} \mathrm{h}^{-1} \mathrm{~m}^{-2}$, plume $=0.063 \mathrm{~g} \mathrm{C} \mathrm{h}^{-1} \mathrm{~m}^{-2}$ ). Thus, if plume-associated reduction in total water column productivity occurs, it is likely to be limited to a small and remote portion of the plume and of minor significance to the bulk processes and productivity of the plume.

Several authors have previously reported daily productivity data for the GOM. For non-plume coastal regions, these estimates range between 0.3 and $0.5 \mathrm{~g} \mathrm{C}$ $\mathrm{d}^{-1} \mathrm{~m}^{-2}$ (Vargo et al. 1987). Coastal waters impacted by the plume have been reported to exhibit productivity between 0.68 and $5 \mathrm{~g} \mathrm{C} \mathrm{d}^{-1} \mathrm{~m}^{-2}$ (Lohrenz et al. 1999, Chen et al. 2000). Estimates for the offshore GOM are in the range of 0.14 to $0.48 \mathrm{~g} \mathrm{C} \mathrm{d}^{-1} \mathrm{~m}^{-2}$ (Lohrenz et al. 1999). More recently, Chen et al. (2000) estimated productivity at 0.24 and $0.52 \mathrm{~g} \mathrm{C} \mathrm{d}^{-1} \mathrm{~m}^{-2}$ for the open and coastal Gulf waters, respectively. Based on our remote sensing analysis, roughly $15 \%$ of the GOM exhibits an elevated chl a signature due to coastal proximity (data not shown), while the remaining $85 \%$ can be characterized as offshore and oligotrophic. If 0.5 and $0.25 \mathrm{~g} \mathrm{C}$ $\mathrm{d}^{-1} \mathrm{~m}^{-2}$, respectively, are used as averages for integrated coastal and open ocean carbon fixation, then total GOM productivity can be estimated at ca. $4.1 \times$ $10^{11} \mathrm{~g} \mathrm{C} \mathrm{d}^{-1}$. Assuming a rate of carbon fixation in the plume of $3.28 \times 10^{9} \mathrm{~g} \mathrm{C} \mathrm{h}^{-1}$ for $12 \mathrm{~h} \mathrm{~d}^{-1}$ occurring in the upper $10 \mathrm{~m}$ of the water column, it can be estimated that the plume accounted for as much as $13 \%$ of all primary production in the oligotrophic GOM during July of 2001, while covering less than $2.8 \%$ of its area.

Critical to the quality and quantity of POC export to the deep ocean is the makeup of the oceanic food web. Picoplankton dominated recycled production is not thought to lead to significant export of surface production to the deep ocean. Larger eukaryotic phytoplankton such as diatoms and coccolithophorids on the other hand may display appreciable sinking rates and are also important food sources for higher trophic levels. In the northern GOM in particular these assumptions have been investigated for several relevant eukaryotic phytoplankton taxa (Fahnenstiel et al. 1995). Growth rates were highest inside the plume region and were also greater during summer. Sinking rates were apparently controlled by the degree of silicification. Sedimentation was important in several diatom species, in particular, large colonial types such as Skeletonema costatum and Thalassiosira rotula. Hence, if significant downward flux of carbon occurs in the offshore plume, it is likely coupled to productivity and growth of a proliferating diatom population in the more remote and less productive portions of the plume.
Our data indicates that diatoms were important in portions of the plume. Cluster and pigment analysis suggest the division of the plume into coastal and offshore diatom dominated regions (Stns 2, 6 and 7) and a Synechococcus dominated mid-plume (Stns 4 and 5). At Stns 4 and 5 Synechococcus accounted for 29 and $56 \%$ of total chl a respectively, while diatoms only accounted for 4.6 and $9.6 \%$ respectively. The reverse was observed for Stns 2, 6 and 7, where diatoms accounted on average for a 4 -fold greater proportion of the chl a pool than Synechococcus, a difference that was significant at the $98 \%$ confidence interval $(\mathrm{p}=$ 0.02). At Stns 2 and 7, the contribution of Synechococcus to total chl a was also significantly lower than at 'non-plume' stations ( $\mathrm{p}=0.092)$.

A total of 35 unique diatom $r b c L$ sequences were recovered from the plume accounting for a remarkable $42 \%$ of all phytoplankton species detected there. Considering this diversity, the diatom pigment signature and the observation that chromophytic rbcL mRNA increased almost 24-fold between Stn 8 and its peak at Stn 4 (Wawrik 2004) it seems that diatoms played an important role in the phytoplankton dynamics and productivity of the plume. Interestingly the companion study (Wawrik 2004) indicated that productivity in the plume was driven mainly by rapid recycling of ammonium. Diatoms are mostly thought to be new producers and to depend on nitrate for growth. Based on our data, it is feasible to hypothesize that diatom production in the plume was driven by ammonium (recycled production). Whether diatom driven recycled production occurs in the plume remains to be demonstrated.

Nitrate input into the Gulf of Mexico by the Mississippi River has at least doubled over the last half century, while silicate concentrations in the river have simultaneously decreased by $50 \%$ (Rabalais et al. 2002). The size and type of diatoms in the plume may, as a consequence, have been limited, reducing the amount of large, heavily silicified forms in the phytoplankton (Turner et al. 1998, Dortch et al. 2001). The impact of these changes on carbon sequestration is not known, but plume productivity may have shifted from diatoms to picocyanobacteria and consequently reduced total carbon flux below the euphotic zone. On the other hand, the increase in nutrients in general has no doubt increased overall production in the plume, potentially leading to greater carbon export.

Nowhere in the plume did diatoms and Synechococcus combined account for more than $61 \%$ of total chl $a$, and in most cases their combined contributions was less than $50 \%$. Other eukaryotic algal groups must therefore be inferred to account for the remaining pigment. Since pigment data suggested that prymnesiophytes were only of minor importance in the plume, it appears that much of the remainder may have been 
contributed by chlorophytes. Fucoxanthin, found in both diatoms and prymnesiophytes, was almost entirely accounted for by diatoms, even in non-plume samples. Also, over $58 \%$ of all prymnesiophyte-like clones were recovered from only 2 non-plume samples (Stns 1 and 8), emphasizing this groups' preference for offshore and oligotrophic environments. Chl $b$ was abundant in the plume and particularly concentrated in the inshore and Synechococcus dominated portion of the plume, where the greatest number of unique green algal clones were detected in our libraries.

Sequence data analysis also indicated that 'Synechococcus plume' samples (Stns 4 and 5) potentially contained an excess of closely related sequences (Fig. 7). An excess of recently diverged lineages is thought to suggest a highly variable environment where extreme conditions drive rapid microbial evolution. Stns 4 and 5 are located in the transition zone between the coastal shelf associated and the offshore plume. It is possible that highly variable chemical and physical characteristics in the region foster rapid evolutionary processes characterized by frequent invasion and reinvasion of both coastal and oligotrophic species. Alternatively, it is possible that the observed shift was due to primer biases resulting in the absence of the dominant Synechococcus from our libraries. There was a conspicuous lack of Synechococcus-like rbcL sequences in the libraries obtained from Stns 4 and 5. It is possible that the large population of Synechococcus observed at these sites was transcriptionally inactive or dying and was, as a result, not recovered by our RNA based sampling strategy. More likely, however, this population was not detected due to small genetic differences between the naturally occurring strains of Synechococcus in the upper plume and the cultured representatives used in the design of our PCR primer set. Support for this hypothesis is lent by the observation that the $r b c L$ sequences of several green Synechococcus strains isolated from the plume could not be amplified using our PCR primer set (data not shown).

Noteworthy is also the presence of several uncommon sequences in our libraries. One clone (WS01ST7CH3) appeared most closely related to $r b c L$ sequences of the recently described algal class Bolidophycheae (Guillou et al. 1999a), yielding the first evidence for the presence of this algal group in the GOM. Bolidophytes have, however, been demonstrated to constitute only a minor component of the eukaryotic phytoplankton in the equatorial Pacific and Mediterranean Sea (Guillou et al. 1999b) and are likely of minor importance in the plume. Also, we observed several $r b c L$ sequences which formed a small clade clustering basally to the remaining heterokont algae, yet had no apparent close match in GenBank (as of September 2002). We have recovered representatives of this clade during 2 separate cruises (1999 and 2001), both within and outside of the plume (Fig. 4), suggesting the abundance of this unknown taxonomic algal group.

In summary, it appears that our sampling transect traversed 3 oceanographic regimes containing distinct phytoplankton assemblages. Non-plume communities were numerically dominated by Prochlorococcus as determined by flow cytometry and were the preferred environment of prymnesiophytes, eustigmatophytes and haptophytes. The plume was divided into 2 regimes: one Synechococcus dominated, the other diatom dominated. Our data suggest that least productive portions of the plume were dominated by a diverse group of diatoms, indicating the possibility of significant carbon export to below the mixed layer in the oligotrophic NE GOM. High productivity in the Mississippi plume significantly enhanced basin-wide production accounting for as much as $43 \%$ of total oligotrophic surface productivity in the GOM, at least during July of 2001, while covering less than $3 \%$ of its surface area.

Acknowledgements. This research was supported by the Office of Science (BER), US Department of Energy, Grant No. DE-FG02-97ER62452.

\section{LITERATURE CITED}

Carpenter EJ, Lively JS (1980) Review of estimates of algal growth using ${ }^{14} \mathrm{C}$-tracer techniques. In: Falkowski PG (ed) Primary productivity in the sea. Plenum Press, New York, p 171-178

Chen X, Lohrenz SE, Wiesenburg DA (2000) Distribution and controlling mechanisms of primary production on the Louisiana-Texas continental shelf. J Mar Syst 25:179-207

Chin-Leo G, Benner R (1992) Enhanced bacterioplankton production and respiration at intermediate salinities in the Mississippi River plume. Mar Ecol Prog Ser 87:97-103

Claustre HP, Kerherve P, Marty JC, Prieur L, Videau C, Hecq JH (1994) Phytoplankton distribution associated with a geostrophic front: ecological and biochemical implications. J Mar Res 52:711-742

Dortch Q, Rabalais NN, Turner RE, Qureshi NA (2001) Impacts of changing $\mathrm{Si} / \mathrm{N}$ ratios and phytoplankton species composition. In: Rabalais NN, Turner RE (eds) Coastal hypoxia: consequences for living resources and ecosystems, Vol 58. American Geophysical Union, Washingtion, DC, p 37-48

Fahnenstiel GL, McCormick MJ, Lang GA, Redalje DG, Lohrenz SE, Markowitz M, Wagoner B, Carrick HJ (1995) Taxon-specific growth and loss rates for dominant phytoplankton populations from the northern Gulf of Mexico. Mar Ecol Prog Ser 117:229-239

Fox LE, Lipshultz L, Kerkof L, Wofsy SC (1987) A chemical survey of the Mississippi estuary. Estuaries 10:1-12

Grimes CB (2001) Fishery production and the Mississippi River discharge. Fisheries 26:17-26

Guillou L, Dinet MJC, Medlin LK, Claustre H, Loiseaux de Goer S, Vaulot D (1999a) Bolidomonas: a new genus with two species belonging to a new algal class, the Bolidophycease (Heterokonta). J Phycol 35:368-381 
Guillou L, Moon-Van Der Staay SY, Claustre H, Partensky F, Vaulot D (1999b) Diversity and abundance of Bolidophyceae (Heterokonta) in two oceanic regions. Appl Environ Microbiol 65:4528-4536

Justic D, Rabalais NN, Turner RE (1996) Effects of climate change on hypoxia in coastal waters: a doubled $\mathrm{CO}_{2}$ scenario for the northern Gulf of Mexico. Limnol Oceanogr 41:992-1003

Kana TM, Glibert PM (1987) Effect of irradiances up to $200 \mu \mathrm{E}$ $\mathrm{m}^{2} \mathrm{~s}^{-1}$ on the marine Synechococcus WH7803, 2: photosynthetic responses and mechanisms. Deep-Sea Res 34: 497-516

Kumar S, Tamura K, Nei M (1993) MEGA: Molecular Evolutionary genetic analysis. The Pennsylvania State University, University Park, PA

Letelier RM, Bindigare RR, Hebel DV, Andrusek M, Winn CD, Karl DM (1993) Temporal variability of phytoplankton community structure based on pigment analysis. Limnol Oceanogr 38:1420-1437

Lohrenz SE, Dagg MJ, Whitledge TE (1990) Enhanced primary production at the plume/oceanic interface of the Mississippi River. Cont Shelf Res 7:639-664

Lohrenz SE, Fahnenstiel GL, Redalje DG (1994) Spatial and temporal variations of photosynthetic parameters in relation to environmental conditions in northern Gulf of Mexico waters. Estuaries 17:779-795

Lohrenz SE, Fahnenstiel GL, Redalje DG, Lang GA, Chen X, Dagg MJ (1997) Variations in primary production of northern Gulf of Mexico continental shelf waters linked to nutrient inputs from the Mississippi River. Mar Ecol Prog Ser 155:45-54

Lohrenz SE, Wiesenburg DA, Arnone RA, Chen X (1999) What controls primary production in the Gulf of Mexico? In: Sherman K, Kumpf H, Steidinger K (eds) The Gulf of Mexico large marine ecosystem: assessment, sustainability, and management. Blackwell Scientific, Malden, MA, p $151-170$

Martin AP (2002) Phylogenetic approaches for describing and comparing the diversity of microbial communities. Appl Environ Microbiol 68:3673-3682

Millie DR, Pearl HW, Hurley JP (1993) Microalgal pigment assessments using high-performance liquid chromotogrphy: a synopsis of organismal and ecological applications. Can J Fish Aquat Sci 50:2513-2527

Milliman JD, Meade RH (1983) World-delivery of river sediment to the oceans. J Geol 91:1-21

Moody CL (1967) Gulf of Mexico distributive provinces. Am Assoc Petrol Geol Bull 51:179-199

Morel A (1997) Consequences of a Synechococcus bloom on the optical properties of oceanic (case 1) waters. Limnol Oceanogr 42:1776-1754

Editorial responsibility: Jed Fuhrman,

Los Angeles, California, USA
Müller-Karger FE, Walsch JJ, Evans RH, Meyers MB (1991) On the seasonal phytoplankton concentrations and sea surface temperature cycles of the Gulf of Mexico as determined by satellites. J Geophys Res 96:12645-12665

Pakulski JD, Benner R, Amon R, Eadie B, Whitledge TE (1995) Microbial metabolism and nutrient cycling in the Mississippi River plume: evidence for intense nitrification at intermediate plume salinities. Mar Ecol Prog Ser 117: 207-218

Paul JH, Alfreider A, Wawrik B (2000) Micro- and macrodiversity in rbcL sequences in ambient phytoplankton populations from the southeastern Gulf of Mexico. Mar Ecol Prog Ser 198:9-18

Perez R, Muller-Karger FE, Victoria I, Melo N, Cerdeira S (1999) Cuban, Mexican, U.S. researchers probing mysteries of Yucatan Current. EOS Trans Am Geophys Union 80: 153-158

Rabalais NN, Turner RE, Dortch Q, Wiseman WJ, Gupta BKS (1996) Nutrient changes in the Mississippi River and system responses on the adjacent continental shelf. Estuaries 19:386-407

Rabalais NN, Turner RE, Dortch Q, Justic D, Bierman VJ Jr, Wiseman WJ Jr (2002) Nutrient-enhanced productivity in the northern Gulf of Mexico: past, present and future. Hydrobiologia 475:39-63

Redalje DG, Lohrenz SE, Fahnenstiel GL (1994) The relationship between primary production and the vertical export of particulate organic matter in a river-impacted coastal ecosystem. Estuaries 17:829-838

Riley GA (1937) The significance of the Mississippi River drainage for biological conditions in the northern Gulf of Mexico. J Mar Res 1:6074

Turner RE, Qureshi NA, Rabalais NN, Dortch Q, Justic D, Shaw RF, Cope J (1998) Fluctuating silicate:nitrate ratios and coastal plankton food webs. Proc Natl Acad Sci USA 95:13048-13051

Vargo GA, Carder KL, Gregg W, Shanley E, Heil C (1987) The potential contribution of primary production by red tides to the west Florida shelf ecosystem. Limnol Oceanogr 32: 762-767

Walsh JJ (1988) On the nature of continental shelves. Academic Press, San Diego, CA

Wawrik B, Paul JH, Bronk DA, John D, Gray M (2004) High rates of ammonium recycling drive phytoplankton productivity in the offshore Mississippi River plume. Aquat Microb Ecol 35:175-184

Wawrik B, Paul JH, Campbell L, Griffin D, Houchin L, Fuentes-Ortega A, Müller-Karger F (2003) Vertical structure of the phytoplankton community associated with a coastal plume in the Gulf of Mexico. Mar Ecol Prog Ser 251:87-101

Submitted: August 27, 2003; Accepted: January 8, 2004 Proofs received from author(s): April 2, 2004 